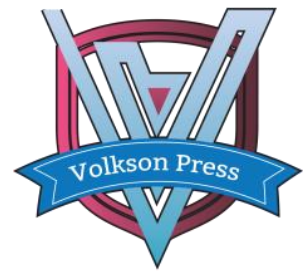

Contents List available at VOLKSON PRESS

Economics \& Management Innovations(EMI)

DOI : http://doi.org/10.26480/icemi.01.2017.56.58

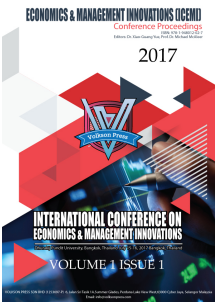

\title{
A Comprehensive Understanding of Territorial Disputes in the South China Sea
}

Wu Fan

Wuhan University of Technology, Wuhan ,China

Email: wuzong888@vip.qq.com

This is an open access article distributed under the Creative Commons Attribution License, which permits unrestricted use, distribution, and reproduction in any medium, provided the original work is properly cited.

\section{ARTICLE DETAILS}

\section{Article History:}

Received 02 october 2017

Accepted 06 october 2017

Available online 11 october 2017

\section{Keywords:}

SVAR, Currency Value, Bernanke-

Mihov Matrix, Southeast-East Asia.

\section{ABSTRACT}

The dispute in the South China Sea involves both island and maritime claims.Key factors should be China, Vietnam,Philippine and the United States.Some claims of every claimant overlap with each other.The ASEAN, the forces outside the region seem to make the dispute multilateral and international.When analyzing the reasons why the dispute emerged, we should take into account the natural resources, the strategic location and historical reasons and so on.Publicists concerning this dispute introduce many theories and international laws in force, among which UNCLOS should be paid special attention to.As for settlement when taking the position as a Chinese, use of force is not impossible since the United States has challenged China's sovereignty by sending destroys or bombers.But the most suitable way is through agreements within the parties to the disputes in accordance with international law.Rome is not built in one day.The agreement can begin with aspects like freedom of navigation, leaving the tough territorial claims last to be dealt.

\section{INTRODUCTION.}

The South China Sea is a marginal sea that is part of Pacific Ocean, encompassing an area from the Singapore and Malacca Straits to the Strait of Taiwan of around 3,500,000 square kilometers.In recent years, territorial disputes in the South China Sea involve both island and maritime claims among several sovereign states within the region.The core issue some commentators concluded is concerned with the Spratly islandsand Parace islands, as well as some conflicts of boundaries.

There are several claimants who announced claims to island territory or maritime rights.Among them are the People's Republic of China (PRC),Taiwan,Vietnam,Philippine, Malaysia, and Brunei.Other forces also displayed their interest in involving in the dispute, mainly India and the United States.

\section{Possible reasons for the dispute}

\subsection{Crude oil and natural gas}

The area may be rich in crude oil and natural gas deposits; however, the estimates are highly varied. The Ministry of Geological Resources and Mining of the People's Republic of China estimate that the South China Sea may contain 17.7 billion tons of crude oil (compared to Kuwait with 13 billion tons). In the years following the announcement by the ministry, the claims regarding the South China Sea islands intensified.

On 27 March 1984, the first Philippine oil company discovered an oil field off Palawan, which is an island province bordering the South China Sea and the Sulu Sea. These oil fields supply $15 \%$ of annual oil consumption in the Philippines.

Vietnam and Japan reached an agreement early in 1978 on the development of oil in the South China Sea. As of 2012, Vietnam had concluded some 60 oil and gas exploration and production contracts with various foreign companies.As of 2011, Vietnam was the sixth-largest oil producer in the Asia- Pacific region.

\subsection{Fishing opportunities}

The abundant fishing opportunities within the region are another motivation for the claim. In 1988,

the South China Sea is believed to have accounted for $8 \%$ of world fishing catches, a figure that has grown since then.

\subsection{Strategic location}

The area is also one of the busiest shipping routes in the world. In the 1980s, at least 270 merchant ships used the route each day. Currently, more than half the tonnage of oil transported by sea passes through it, a figure rising steadily with the growth of Chinese consumption of oil. This traffic is three times greater than that passing through the Suez Canal and five times more than the Panama Canal.In 2012 the Indian Ambassador to Vietnam, while expressing concern over rising tension in the area, said that 50 percent of its trade passes through the area.

\subsection{Other reasons}

In 1950, after the Chinese nationalists were driven by the People's Liberation Army (PLA), they withdrew their garrisons in both the Paracels and Spratlys to Taiwan, leaving plenty of islands vacuum for foreign forces to penetrate.

13 May 2009 is the deadline for states to make seabed claims under the United Nations Convention on the Law of the Sea. This is suspected to have caused ancient island claims to surface and become inflamed.

\section{Public international laws or theories likely invoked}

\subsection{UNCLOS}

When seeking for sources of law governing the dispute concerned, UNCLOS is often invoked.UNCLOS defines the rights and responsibilities of nations with respect to their use of the world's oceans and it came into force in 1994.Let me introduce some provisions of UNCLOS. Article 74 of UNCLOS provide that:

1. The delimitation of the exclusive economic zone between States with opposite or adjacent coasts shall be effected by agreement on the basis of international law, as referred to in Article 38 of the Statute of the International Court of Justice, in order to achieve an equitable solution;

2. If no agreement can be reached within a reasonable period of time, the States concerned shall resort to the procedures provided for in Part XV.

3. Pending agreement as provided for in paragraph 1, the States concerned, in a spirit of understanding and cooperation, shall make every effort to enter into provisional arrangements of a practical nature and, during this transitional period, not to jeopardize or hamper the reaching of the final agreement. Such arrangements shall be without prejudice to the final delimitation. 
As for article 83 of UNCLOS, the clause uses the same context as provided for in article 74 except the phrase exclusive economic zone is replaced by phrase of the continental shelf.

\section{Article 279 of UNCLOS provides that:}

In any dispute involving scientific or technical matters, a court or tribunal exercising jurisdiction under this section may, at the request of a party or Proprio Motu, select in consultation with the parties no fewer than two scientific or technical experts chosen preferably from the relevant list prepared in accordance with Annex VIII[1], article 2, to sit with the court or tribunal but without the right to vote. So, UNCLOS makes clear that the procedure should be like this: if parties pend agreement, a provisional arrangements should be reached; if a final agreement is concluded, the dispute ends; but if no agreement is reached within a reasonable period, parties to the dispute shall resort to a court or tribunal having jurisdiction.And the court or tribunal shall be opened at the request of a party or Proprio Moto.

In fact,I do think that our county holds a wrong position when facing the case put forward by Philippine.In my opinion, we should not be afraid of such jury.Law coming into force should mean

\section{something.And from all aspects,I think China will win the battle.}

\subsection{Theory of preempting and historical evidence}

China is the first to discovery the archipelagos, name them, exercise jurisdiction.We can trace back to Han dynasty.Before Han dynasty, South China Sea is so called res nullius.In accordance with international law, China deserves the South China Sea.And what should be paid more attention is that China exercise persists jurisdiction and receive no territory claims from other nations till the 1930s when France invaded Paracel Islands and the Spratly Islands[2].What is more, it should be pointed out that considering the laggard technology and inconvenient transportation, the criteria should be less strict when adopting the theory of preempting.

Then here comes the validity of historical evidence.For instance,the legacy of the nine-dotted line is viewed by some Chinese government officials, and by the Chinese military, as providing historical support for the claims to the South China Sea.How to explain and decide the validity becomes vital to Chinese claims.Basic trend of ICJ is to decide and choose standards at the time when the evidence is considered. while some publicists in China argue that we need to adopt the criteria when the evidence concerned was forged Different methods lead to a different conclusion. Anyway, when taking account of historical evidence, it is good for Chinese.

\subsection{Theory of actual control}

There is also an important theory called actual control. Well, this is more practical and it seems easy to handle the dispute.But this theory pays little attention to history thus won't be approved by many states.

Taiwan garrisons Pratas Islands at present, while mainland China controls Paracel Islands and Philippine takes control of Macclesfield Islands. As for the Spratly Islands, it is more complicated since Vietnam occupies 29 islands, Philippine 8 islands, Malaysia 5 islands, Brunei 2 islands and with mainland China and Taiwan 2 and 7 respectively.

If this theory is adopted, we shouldn't ignore the subsequent effect. Does it mean it is legal and right when a state deploys its army and sends them when it wants to hold some territory of other states?

\subsection{Historical archipelago waters}

These historical archipelago waters theory is put forward by some radical publicists. China long holds the stand that the islands in the South China Sea are Chinese land territories and these land territories have their own territory sea, Exclusive Economic Zone, and continent shelf.As for other waters, China puts forward that it enjoys "historical rights".Some radical publicists argue that this may not be the perfect way to protect China's rights.They put forward historical archipelago waters theory.UNCLOS has already adopted the archipelago water system.To be an archipelago water there is a condition under which the size ratio of land and water should fulfill some requirements.And the situation in the South China Sea does not match.So, some publicists jump out of the UNCLOS and invent the theory. This theory is just an effort made by radical publicists who want to provide the basis for Chinese claims.
Philippine has some new theories, too.There are principles of safety, principles of adjacence, principle of res nullius--that is because Taiwan withdraws its army when it is defeated by mainland China thus leaving some islands without garrisons.

After the UNCLOS came into effect, principles of the continent shelf and Exclusive Economic Zone appear.I must say these are without logical reasoning.According to UNCLOS, a definite territory is the premise of systems contained therein.We can not occupy territory on the basis of the continent shelf and so on

\section{Mechanisms of dispute settlement}

\subsection{Use of force}

As of the signing of Act of Paris in 1928, the use of war to solve international disputes is prohibited.In 1945, the UN charter explicitly provided that all members of UN shall refrain in their international relations from the threat or use of force against the territorial integrity or political independence of any state, or in any other manner inconsistent with the purposes of the United Nations [3].Only in two situations can force be used--to defend the state or in the name of authorization of UN Security Council.

On October 2011, China's Global Times newspaper, published by the Communist Party, People's Daily, editorialized on South China Sea territorial disputes under the banner "Don't take a peaceful approach for granted". The article referenced recent incidents involving the Philippines and South Korea detaining Chinese fishing boats in the region:

"If these countries don't want to change their ways with China, they will need to prepare for the sounds of cannons. We need to be ready for that, as it may be the only way for the disputes in the sea to be resolved." Global Times (China), 25 October 2011 Responding to questions about whether this reflected official policy, a Chinese Foreign Ministry spokeswoman stated the country's commitment "to resolving the maritime dispute through peaceful means."

In fact, back In 1984, Deng Xiaoping raised two options to choose to resolve the dispute: "One method is that we use force to get these islands back. Another is to shelve the sovereignty issue, co-develop the place."

\subsection{Three kinds of approaches}

According to some professors, there are three kinds of ways to solve the issue.These are the unilateral approach, bilateral approach, and multilateral approach.Then, which one is better or suitable?Can it be possible that more than one approach is adopted?

As for unilateral approach, we need fast know that sometimes it's legal and helpful.For example, if a state to a dispute makes a comprise formally and legally, no one doubts that this will promote the settlement of the dispute in question.However, this seems impossible when encountering the dispute in the South China Sea. Philippine unilaterally passed a law called as "law of baseline of territorial sea" in 2009, regardless of oppositions of around nations, which only resulted in exacerbating the dispute.

But we do have an example showing the success of the bilateral approach.The bilateral approach means two countries to a dispute involve in negotiation and bilateral treaty to solve their problems.In 2001, China and Vietnam adopted a treaty delimiting the boundary of Gulf of Ton-kin.This treaty serves as deciding the delimitation of Ton kin Gulf and the ownership of maritime rights and it works well.But this kind of approach can only be used in special occasions under which a dispute is merely involved with two parties.We have known that different states or parties in the South China Sea have different claims and often these claims overlap with each other.In other words, there are several disputes in the South China Sea, each of which involved a different collection of countries.Besides when adopting the bilateral method, there is a possibility that the signing parties will conclude a treaty harming the rights of the third party.

The third approach is multilateral.In 2002, there is an example.China and ASEAN signed the Declaration on the Conduct of Parties in the South China Sea.The core terms are the fourth and fifth clause.The content is as follows: The Parties concerned undertake to resolve their territorial and jurisdictional disputes by peaceful means, without resorting to the threat or use of force, through friendly consultations and negotiations by sovereign states directly concerned, in accordance with universally recognized principles of 
that would complicate or escalate disputes and affect peace and stability including, among others, refraining from action of inhabiting on the presently uninhabited islands, reefs, shoals, cays, and other features and to handle their differences in a constructive manner[4].

These words are perfect except that this declaration is only a declaration in political, not legally.Nations concerned violate the declaration from time to time without penalty.

\subsection{Arbitration or judiciary}

Whether to choose arbitration or judiciary, it is a dilemma for China.Because there will always be a precedent question of Taiwan.What status does Taiwan belong to?Should it be necessary to solve the issue of Taiwan first? So, in China, there are callings that call on China to avoid arbitration and judiciary as possible as we can

In 2014, Philippine invoked the compulsory settlement of dispute clause under UNCLOS by submitting a case to the Permanent Court of Arbitration in The Hague against China over South China Sea claims.So it is necessary to have more look at UNCLOS.

\section{Article 287 of UNCLOS provides that:}

1. When signing, ratifying or acceding to this Convention or at any time thereafter, a State shall be free to choose, by means of a written declaration, one or more of the following means for the settlement of disputes concerning the interpretation or application of this Convention:

(a) the International Tribunal for the Law of the Sea established in accordance with Annex VI;

(b) the International Court of Justice;

(c) an arbitral tribunal constituted in accordance with Annex VII;

(d) a special arbitral tribunal constituted in accordance with Annex VIII for one or more of the categories of disputes specified therein.

2. A State Party, which is a party to a dispute not covered by a declaration in force, shall be deemed to have accepted arbitration in accordance with Annex VII.

3. If the parties to a dispute have accepted the same procedure for the settlement of the dispute, it may be submitted only to that procedure, unless the parties otherwise agree.

4. If the parties to a dispute have not accepted the same procedure for the settlement of the dispute, it may be submitted only to arbitration in accordance with Annex VII, unless the parties otherwise agree. Article 288 of UNCLOS provides:

5. In the event of a dispute as to whether a court or tribunal has jurisdiction, the matter shall be settled by the decision of that court or tribunal.

It is clear that members of UNCLOS can unilaterally submit the case to arbitration.Whether the tribunal or court has the jurisdiction should be decided by the court or tribunal, not member states.

China has asserted that she would not accept, or get involved in the case submitted by Philippine for the tribunal did not have the jurisdiction.Obviously, this is wrong.According to UNCLOS, the procedure will continue even without Chinese participate.There are two stages, one is for the tribunal to consider whether it has jurisdiction, while another is to consider the essential matters.Because China is not at present when the first stage moves on, we failed.What a pity!
First of all, we need to participate in the arbitration.What if we win at the jurisdiction procedure?Then the other claimants in the South China Sea as well as Philippine will learn a lesson.And if we fail, which happens in reality, we can follow suit as the United States did before: we can announce to quit the essential procedure.

Second, quitting the UNCLOS does not mean we lock ourselves once again.The United States is not

a member of UNCLOS, but has accepted all but Part XI as customary international law.

\section{Conclusions}

The dispute in the South China Sea is essentially a delimitation issue.It is a political dispute as well as a dispute in law.It involves both island and maritime claims among several sovereign states within the region.Forces outside the region and ASEAN also play a role.The pivot of the dispute is involved with both the Spratly and the Paracel islands.

The reason why this dispute emerges should be the interests of different nations including acquiring fishing areas around the two archipelagos; the potential exploitation of suspected crude oil and natural gas under the waters of various parts of the South China Sea; and the strategic control of important shipping lanes.

It can not be denied that there is a way to go to settle the problem in the South China Sea.Anyway, we should be committed to settling the dispute through legal methods but not political announcements; negotiate with the relative parties at dispute directly but not through association of southeast Asian nations.And the dispute should be settled step by step.First, we solve some easier aspects such as marine environmental protection, scientific research, the safety of navigation and communication, search and rescue and combating transnational crime and so on.In the end, we focus on issues of oil and natural gas drilling and territory sovereignty.

\section{References}

[1] Treves T. Law and Science in the Interpretation of the Law of the Sea Convention[J]. Journal of International Dispute Settlement, 2012, 3(3).

[2] Song Y H. The potential marine pollution threat from oil and gas development activities in the disputed South China Sea/Spratly Area: a role that Taiwan can play[J]. Ocean Development \& International Law, 2008, 39(2): 150-177.

[3] Vidmar J. Conceptualizing Declarations of Independence in International Law[J]. Oxford JL Stud., 2011, 32: 153, 166.

[4] Information on http://www.economist.com/news/asia/21660486dont-mention-sea-china-wants- its-neighbours-not-talk-about-big-issue

[5] Rusli M H B M. Protecting vital sea lines of communication: A study of the proposed designation of the Straits of Malacca and Singapore as a particularly sensitive sea area[J]. Ocean \& Coastal Management, 2012, 57: 79-94.

[6] Wang P. Co-operative survey[J]. Marine Geology, 1981, 40(3-4): 277-278.

[7] Henriksen T, Ulfstein G. Maritime Delimitation in the Arctic: The Barents Sea Treaty[J]. Ocean Development \& International Law, 2011, 42(1-2): 1-21.

[8] Raine S. Beijing's South China Sea Debate[J]. Survival, 2011, 53(5): 6988.

[9] Hu N T A. South China Sea: Troubled Waters or a Sea of Opportunity[J]. Ocean Development \& International Law, 2010, 41(3): 203-213.

[10] Zimmermann A, Bäumler J. Navigating Through Narrow Jurisdictional Straits: The Philippines- PRC South China Sea Dispute and UNCLOS[J]. The Law \& Practice of International Courts and Tribunals, 2013, 12(3): 431-461.

Maybe we should learn from the United States. 